\title{
Neonatális Intenzív Centrumban ellátást igénylö betegeink anyai széles spektrumú béta-laktamáz-termeló baktériummal történt kolonizációjának vizsgálata és követése
}

\author{
Patyi Márta dr. ${ }^{1}$. Tóth Zsuzsanna ${ }^{1}$ - Kelemen Edit ${ }^{2}$ - Tálosi Gyula dr. ${ }^{2}$ \\ Bács-Kiskun Megyei Kórház, ${ }^{1}$ Kórházhigiénés Osztály, \\ ${ }^{2}$ Gyermekosztály, Kecskemét
}

\begin{abstract}
Bevezetés: A széles spektrumú béta-laktamáz-termelő bélbaktériumok várandósok és koraszülöttek vastagbelében is tünetmentes hordozást okozhatnak. Célkitüzés: A szerzők intézményében felmérték a szülés napján azon édesanyák között e kórokozó hordozásának gyakoriságát, akiknek a gyermeke Neonatalis Intenzív Centrumba került felvételre, azzal a céllal, hogy megakadályozzák a felismert kolonizált édesanyák újszülöttjeiben a kolonizáció kialakulását. Módszer: 2013. október 1. és 2015. október 31. között a koraszülés napján az édesanyák szúrését végezték. 751 esetben levett anorectalis törlés vagy székletminta 19 esetben adott pozitív eredményt. A pozitív mintájú édesanyák személyre szóló higiénés oktatásban részesültek kézhigiéné témakörben. A gyermekek ellátásában ezt követően aktívan részt vettek. Egyes gyermekektől a felvétel napján gyomormosó folyadékból és fülváladékból mintát küldtek tenyésztésre, majd kórházi kezelésük alatt minimum egy alkalommal anorectalis szürést végeztek széles spektrumú béta-laktamázt termelő kórokozó okozta kolonizáció irányába. Eredmények: A 19 pozitív mintájú édesanya egyetlen újszülöttje sem vált pozitívvá a megfigyelés ideje alatt. Következtetés: Felismert anyai kolonizáció esetén a kórházhigiénés szabályok betartásával a terjedés megelózhető. Orv. Hetil., 2016, 157(34), 1353-1356.
\end{abstract}

Kulcsszavak: széles spektrumú béta-laktamáz-termelő bélbaktérium, koraszülött, kolonizáció

\section{Examination of maternal extended spectrum beta-lactamase bacterial colonization and follow-up of newborns requiring Neonatal Intensive Care Unit admission}

\begin{abstract}
Introduction: The extended beta-lactamase producing Enterobacteriaceae may cause asymptomatic carriage if present in the colon of premature infants or pregnant women. Aim: To assess the incidence of colonization among mothers whose infants were admitted to Neonatal Intensive Center on the day of their delivery for this pathogen. Method: From October 1, 2013 until October 31, 2015 the authors screened mothers on the day of their delivery for this pathogen. Nineteen of the 751 anorectal swabs or stool samples were found to be positive. Mothers having positive samples were given personal education for hand hygiene, then they actively participated in the care of their babies. From some premature infants ear swab and stomach washing were taken and sent for culture on the day of their admission. In the course of their hospital stay, anorectal swabs were taken and screened for this bacteria colonization at least once. Results: None of the premature infants of the 19 extended beta-lactamase producing Enterobacteriaceae-positive mothers became positive in the studied period. Conclusion: If the mother is colonized, the spreading of pathogen to newborns can be prevented by observing the hygienic rules.
\end{abstract}

Keywords: extended spectrum beta-lactamase producing Enterobacteriaceae, premature infant, colonization

Patyi, M., Tóth, Zs., Kelemen, E., Tálosi, Gy. [Examination of maternal extended spectrum beta-lactamase bacterial colonization and follow-up of newborns requiring Neonatal Intensive Care Unit admission]. Orv. Hetil., 2016. $157(34), 1353-1356$

(Beérkezett: 2016. május 2.; elfogadva: 2016. június 3.) 


\section{Rövidítések}

$\mathrm{ESBL}=$ (extended spectrum beta-lactamase) széles spektrumú béta-laktamáz; NIC $=($ Neonatal Intensive Center $)$ Neonatális Intenzív Centrum

A béta-laktám-csoportba a penicillinek, cefalosporinok és a karbapenemek tartoznak. Az alapvázukat képező béta-laktám-gyưrưroól kapták nevüket. A béta-laktámok a baktériumok sejtfalszintézisében részt vevő fehérjéhez kötődve gátolják a sejtfalképzést. A velük szembeni rezisztencia béta-laktamáz-termeléssel, a kötő fehérje, illetve a sejtfal permeabilitásának változásával jöhet létre [1]. A penicillineket lebontó penicillináztermelő Escherichia (E.) coliról az első közlés 1940-ben volt. A bétalaktamázok olyan enzimek, amelyek képesek hidrolizálni a béta-laktám-gyúrút. A széles spektrumú béta-laktamáz- (ESBL-) termelő bélbaktériumok a 3. generációs cefalosporinokat is képesek lebontani, leírásukra 1983ban került sor. Az ESBL-termelés az Enterobacteriaceaecsoport tagjaiban található meg leggyakrabban, főleg a Klebsiella species, Escherichia (E.) coli és Proteus (P.) mirabilis fajokban. Szinte minden bélbaktériumban leírásra kerültek már. Ezek a kórokozók a béta-laktám és monobactam antibiotikumokon túl gyakran rezisztensek még a trimethoprim-szulfometoxazol, fluorokinolon- és az aminoglikozidkezelésre is. Előfordulásuk azóta egyre nő. Ezek a kórokozók kolonizálni tudják a vastagbelet, tünetmentes hordozást okozva [2].

Különösen veszélyes lehet az újszülött-intenzívellátást igénylő betegek kolonizációja, amelyet elősegít az intenzív osztályos környezet, a szokásosnál magasabb császármetszési arány, a koraszülöttség és a betegek táplálási zavara, amely gyakran együtt jár a saját anyatej hiányával [3]. A vizsgálatunk célja az volt, hogy megismerjük a szülés napján a Neonatális Intenzív Centrumba (NIC) került újszülöttek édesanyjainak ESBL-kolonizációs státuszát és pozitivitás esetén kórházhigiénés intézkedésekkel megakadályozzuk az anyákról az újszülöttekre történő terjedést.

\section{Módszer}

A behurcolt kolonizáció arányának megismerése érdekében kórházunkban 2013. október 1. és 2015. október 31. között a szülés napján azoknak az édesanyáknak az ESBL-szúrését végeztük el, akiknek gyermeke a gesztációs hét alapján vagy állapota miatt a NIC-be került. A pozitív édesanyák személyre szóló higiénés oktatásban részesültek kézhigiéné témakörben. A gyermekek ellátásában ezt követően aktívan részt vettek és szoptattak is, amennyiben a gyermek állapota ezt megengedte. Egyes gyermekektól a felvétel napján gyomormosó folyadékból és fülváladékból mintát küldtünk tenyésztésre, majd a kórházi kezelésük alatt 8 esetben egyszer, 11 esetben többször (2-4 alkalommal) anorectalis szúrés történt ESBL-kolonizáció irányába.

\section{Eredmények}

751 esetben levett anyai anorectalis törlés vagy székletminta 19 esetben adott pozitív eredményt (1. táblázat), amely 2,5\%-os kolonizációs aránynak felel meg. A 19 gyermek gesztációs idejét, születési súlyát és az intézményünkben töltött ápolási napok számát tartalmazza a 2 . táblázat. Azoknak az ESBL-kolonizált édesanyáknak a gyermekei (11 fó), akiknek az ápolási idejének hossza lehetővé tette, hogy 2 vagy több mintavétel történjen, a kórházi követés alatt negatívak maradtak. A vizsgált újszülöttcsoportból $7 / 19$ volt koraszülött és $2 / 19$ volt

1. táblázat Az elvégzett összes székletvizsgálat (anorectalis törlés és székletminta) és az ESBL-pozitív eredmények

\begin{tabular}{lcccc}
\hline Időszak & $\begin{array}{c}\text { Anorectalis } \\
\text { törlés } \\
\text { mintaszáma }\end{array}$ & $\begin{array}{c}\text { ESBL- } \\
\text { pozitív } \\
\text { mintaszám }\end{array}$ & $\begin{array}{c}\text { Széklet- } \\
\text { ESBL- } \\
\text { szúrés } \\
\text { mintaszáma }\end{array}$ & $\begin{array}{c}\text { ESBL- } \\
\text { pozitív } \\
\text { mintaszám }\end{array}$ \\
\hline $\begin{array}{l}\text { 2013. október } \\
\text { 1. december } \\
\text { 31. }\end{array}$ & 123 & 1 & 2 & 1 \\
$\begin{array}{l}\text { 2014. január 1. } \\
- \text { december 31. }\end{array}$ & 305 & 8 & 5 & 0 \\
$\begin{array}{l}\text { 2015. január 1. } \\
- \text { október 31. }\end{array}$ & 316 & 9 & 0 & 0 \\
\begin{tabular}{l} 
Összesen \\
\hline
\end{tabular} & 744 & 18 & 7 & 1 \\
\hline
\end{tabular}

2. táblázat | A 19 pozitív esethez tartozó születéskori gesztációs idő hetekben megadva, újszülöttek születési súlya és az ápolási napok száma

\begin{tabular}{|c|c|c|c|}
\hline Esetazonosító & $\begin{array}{c}\text { Gesztációs hét } \\
\text { szüléskor }\end{array}$ & $\begin{array}{l}\text { Újszülött születési } \\
\text { súlya (gramm) }\end{array}$ & $\begin{array}{c}\text { Ápolási napok } \\
\text { száma }\end{array}$ \\
\hline 1. & 31 & 2250 & 5 \\
\hline 2. & 38 & 2900 & 5 \\
\hline 3. & 37 & 3400 & 3 \\
\hline 4. & 32 & 1270 & 30 \\
\hline 5. & 34 & 1700 & 29 \\
\hline 6. & 32 & 1490 & 29 \\
\hline 7. & 35 & 2350 & 11 \\
\hline 8. & 34 & 2260 & 26 \\
\hline 9. & 35 & 2500 & 6 \\
\hline 10. & 36 & 2490 & 9 \\
\hline 11. & 37 & 3150 & 8 \\
\hline 12. & 37 & 2700 & 8 \\
\hline 13. & 36 & 2950 & 6 \\
\hline 14. & 40 & 4500 & 9 \\
\hline 15. & 39 & 3950 & 4 \\
\hline 16. & 38 & 3500 & 2 \\
\hline 17. & 38 & 2490 & 17 \\
\hline 18. & 39 & 3700 & 7 \\
\hline 19. & 32 & 1950 & 7 \\
\hline
\end{tabular}


igen kis súlyú, azaz 1500 g-nál kisebb születési súlyú koraszülött. A 19 pozitív édesanya gyermekétől összesen 13 fülváladék, 10 gyomormosó folyadék, 9 torok-, 2 orrváladék, 1 vizelet és 7 hemokultúra levétele mellett 34 anorectalis mintavétel történt. Az átlagos ápolási idő 15,1 nap (2-36 nap) volt. Egy betegünkben sem találtunk ESBL-pozitív mintát, és ESBL-fertőzésre utaló tünetek sem alakultak ki. Mind a 19 beteget hazaadtuk.

\section{Megbeszélés}

Világszerte nő a multirezisztens kórokozók előfordulása. Pontosan még nem ismert a hosszú távú kolonizáció következménye. Nem megoldott a dekolonizáció módja, probiotikumokkal történnek próbálkozások. E kórokozók által kiváltott kórképek kezelése egyre nehezebb [4-6]. A kis születési súly hajlamosít az ESBL-termelő Enterobacteriaceae törzsek megtelepedésére a koraszülöttek bélrendszerében. 48 órán túli kórházi tartózkodás esetén a beteget kolonizáló flóra részévé válnak a kórházi környezetet kolonizáló organizmusok. Lényeges különbségek lehetnek a fenti kórokozó hordozásában országonként. A várandósok is ESBL-termelő Enterobacteriaceae törzseket hordozhatnak tünetmentesen.

Hazánkban a koraszülésen átesett édesanyák ESBLtermelő bélbaktériummal történő kolonizációjára irodalmi adatot nem találtunk. Argentínában a vaginalis ESBLtermelö E. coli kolonizációs arányt terhesek között 5,4\%-osnak találták 2013-ban [7]. Per vias naturales szülés esetén a hüvelyi hordozás át is vihető a koraszülöttre, akár kórházi járványt okozva [8]. A NIC-okban világszerte nagy gondot okoz ezeknek a kórokozóknak az előfordulása és gyakori elterjedése. Járvány esetén fágtipizálási módszerek segítenek azonosítani a kiváltó törzset [9, 10]. Intézményünk NIC-ában 2005 óta fordul elő ESBL-termelő kórokozó, 98,5\%-ban kolonizáció formájában.

A koraszülöttek normális bélflórájának kialakulásához nagyon fontos a saját anyatejes táplálás és a kenguruztatás. Ezek a módszerek a koraszülött családjára jellemző kolonizáló flóra kialakulását segítik elő. Anyai ESBL-termelő Enterobacteriaceae-hordozás esetén azonban kóros bélbaktériumok megtelepedésének a veszélye áll fenn a koraszülöttben is. Az intézményünkben bevezetett higiénés oktatás és szabályok betartása mellett a fenti időszakban, a kórházi tartózkodás alatt nem igazolódott ESBL-termelő bélbaktérium megtelepedése a 19 pozitív édesanya gyermeke esetében.

A kockázati csoportokba tartozó betegek szűrését többen ajánlják [11, 12]. Eredményeink felhívják a figyelmet arra, hogy Magyarországon is jelentős ezeknek a multirezisztens kórokozóknak tünetmentes hordozása az egyébként egészséges terhesekben. Mindezek alapján megfontolandó a szürések rutinszerüvé tétele koraszülés vagy NIC-ba felvételre kerülő újszülött esetén, a koraszülött és a kontakt terhesek védelme érdekében. A felismert kórokozó-hordozás következtében bevezetett kór- házhigiénés intézkedések a kórokozók terjedését megállíthatják. Annak felmérése, hogy a koraszülöttek hazabocsátásuk után pozitívvá válnak-e az otthoni környezetben, egy külön vizsgálat anyagát képezheti.

\section{Következtetés}

Gondos ápolással, a higiéniai szabályok betartásával és a „jó kolonizáció” elősegítésével az intenzív ellátást igénylő újszülöttek ESBL-kolonizációja és ennek esetleges súlyos következményei megelőzhetők.

Anyagi támogatás: A közlemény megírása anyagi támogatásban nem részesült.

Szerzői munkamegosztás: P. M.: Adatgyűjtés, irodalomkutatás, a publikáció megírása. T. Zs., K. E.: Adatgyưjtés, a publikáció átnézése. T. Gy.: Irodalomkutatás, a publikáció átnézése, javítása. A cikk végleges változatát valamennyi szerző elolvasta és jóváhagyta.

Érdekeltségek: A szerzőknek nincsenek érdekeltségeik.

\section{Köszönetnyilvánítás}

A szerzők köszönetet mondanak az igazgatás által nyújtott anyagi támogatásért, a Szülészet-Nőgyógyászat Osztály és a NIC munkatársainak az együttmúködésért.

\section{Irodalom}

[1] Szalka, A., Timár, L., Ludwig, E., et al.: Infectology. [Infektológia.] Medicina Könyvkiadó, Budapest, 2005. [Hungarian]

[2] Patyi, M.: The extended spectrum beta-lactamase producing bacteria as a new problem in our institution. [A széles spektrumú béta-laktamáz termelő kórokozók, mint egy újabb kórházhigiénés problémakör intézményünkben.] Infekció és Infekciókontroll, 2009, 6(1), 59-66. [Hungarian]

[3] Moore, T. A., Hanson, C. K., Anderson-Berry, A.: Colonization of the gastrointestinal tract in neonates. Infant Child Adolescent Nutrition, 2011, 3(5), 291-295.

[4] Pfeifer, ., Cullik, A., Witte, W.: Resistance to cephalosporins and carbapenems in Gram-negative bacterial pathogens. Int. J. Med. Microbiol., 2010, 300(6), 371-379.

[5] Pitout, J. D., Nordmann, P., Laupland, K. B., et al.: Emergence of Enterobacteriaceae producing extended-spectrum beta-lactamases (ESBLs) in the community. J. Antimicrob. Chemother., 2005, 56(1), 52-59.

[6] Wilke, M. S., Lovering, A. L., Strynadka, N. C.: Beta-lactam antibiotic resistance: a current structural perspective. Curr. Opin. Microbiol., 2005, 8(5), 525-533.

[7] Villar, H. E., Aubert, V., Baserni, M. N., et al.: Maternal carriage of extended-spectrum beta-lactamase-producing Escherichia coli isolates in Argentina. J. Chemother., 2013, 25(6), 324-327.

[8] Tschudin-Sutter, S., Frei, R., Battegay, M., et al.: Extended spectrum $\beta$-lactamase-producing Escherichia coli in neonatal care unit. Emerg. Infect. Dis., 2010, 16(11), 1758-1760.

[9] Giuffrè, M., Cipolla, D., Bonura, C., et al.: Outbreak of colonizations by extended-spectrum $\beta$-lactamase-producing Escherichia coli sequence type 131 in a neonatal intensive care unit, Italy. Antimicrob. Resist. Infect. Control, 2013, 2(1), 8. 
[10] Haller, S., Eller, C., Hermes, J., et al.: What caused the outbreak of ESBL-producing Klebsiella pneumoniae in a neonatal intensive care unit, Germany 2009 to 2012? Reconstructing transmission with epidemiological analysis and whole-genome sequencing. BMJ Open, 2015, 5(5), e007397.

[11] Reddy, P., Malczynski, M., Obias, A., et al.: Screening for extended-spectrum beta-lactamase-producing Enterobacteriaceae among high-risk patients and rates of subsequent bacteremia. Clin. Infect. Dis., 2007, 45(7), 846-852.

[12] Tacconelli, E., Cataldo, M. A., Dancer, S. J., et al.: ESCMID guidelines for the management of the infection control measures to reduce transmission of multidrug-resistant Gram-negative bacteria in hospitalized patients. Clin. Microbiol. Infect., 2014, 20(Suppl. 1), 1-55. http://www.escmid.org/escmid_library/ medical_guidelines/escmid_guidelines/

(Patyi Márta dr., Kecskemét, Nyíri út 38., 6000 e-mail: patyim@kmk.hu)

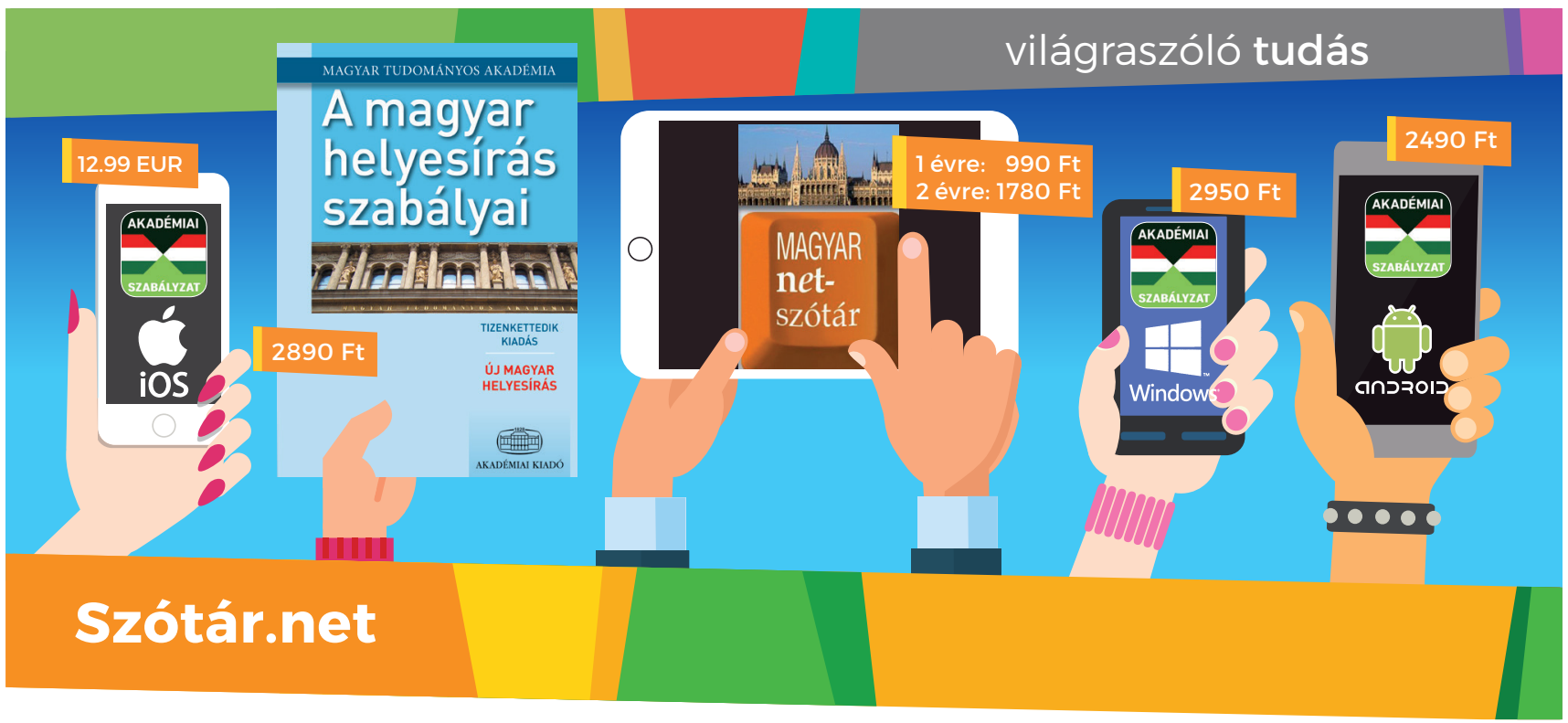

\section{A magyar helyesírás szabályai 12. kiadás}

\section{Mindig a keze ügyében!} \begin{tabular}{l|l} 
- a Magyar Tudományos Akadémia szabályzata & $\begin{array}{l}\text { · a 11. és a 12. kiadás közti különbségek } \\
\text { felsorolása, példákkal } \\
\text { - } 300 \text { szabálypont példákkal }\end{array}$ \\
- szabályzat és szótár egyben & tárató
\end{tabular}

Keresse a könyvet a www.akademiai.hu oldalon, vagy válassza az online változatot és a mobilalkalmazást a www.szotar.net-en!
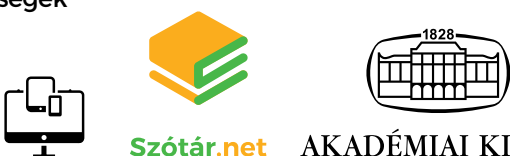

Szótár.net AKADÉMIAI KIADÓ 